\title{
TEM MULHER NA BRINCADEIRA? FALAS FEMININAS, CORPO E DANÇA NA TRADIÇÃO DO CAVALO MARINHO PERNAMBUCANO
}

\section{ARE THERE WOMEN IN THE PLAY? FEMALE VOICES, BODY AND DANCE IN THE TRADITION OF CAVALO MARINHO FROM PERNAMBUCO}

\author{
Tainá Dias de Moraes Barreto ${ }^{1}$
}

\begin{abstract}
Resumo: Este artigo pretende compartilhar uma trajetória de investigação empreendida por uma dançarina-pesquisadora sobre o Cavalo Marinho, brincadeira popular da Zona da Mata Norte de Pernambuco, originalmente feita por homens. O trabalho dialoga com produções de Dança e Teatro que se valem de princípios estéticos, técnicos e expressivos de tradições brasileiras na criação cênica. Com base em imersão em campo, o objetivo do trabalho é refletir sobre a participação das mulheres no Cavalo Marinho. A partir daí, criar uma poética e refletir sobre questões de gênero imbricadas nessa manifestação. Para tanto, propõe-se um deslocamento de olhar justamente para trazer à tona aspectos usualmente não privilegiados nas descrições desse folguedo. O que é bastidor passou a ser objeto de estudo para refletir como a aparente não participação das mulheres determina e molda, de certa maneira, a estética e o funcionamento do Cavalo Marinho.
\end{abstract}

Palavras-chave: Dança; mulheres; cavalo marinho pernambucano.

\begin{abstract}
This paper aims to share the investigation trajectory of a female dancer-researcher and her work on Cavalo Marinho, a traditional form of artistic expression from the northern rural region of Pernambuco - Zona da Mata, also called a "play" and originally made by men. The work dialogues with Dance and Theater productions that use aesthetic, technical and expressive principles of Brazilian traditions in scenic creation. Based on field immersion, the objective of this work is to contemplate the participation of women in Cavalo Marinho, create a poetic and reflect on gender issues embedded in this manifestation. Therefore, it is proposed a shift of look precisely to bring out aspects usually not privileged in the descriptions of this play. What is behind the scenes became the object of study to think how the apparent nonparticipation of women determines the structure and the aesthetics of Cavalo Marinho as well.
\end{abstract} Keywords: Dance; women; cavalo marinho from Pernambuco.

O cavalo marinho, brincadeira popular oriunda da Zona da Mata Norte de Pernambuco, é uma tradição que faz parte da cultura dos trabalhadores rurais ligados ao corte da cana-deaçúcar. Os sujeitos do cavalo marinho são majoritariamente homens e se autodenominam brincadores. Eles se referem ao cavalo marinho como folguedo, festa, samba, brinquedo, brincadeira. As brincadeiras acontecem principalmente em novembro, dezembro e janeiro, compondo o ciclo de festas natalinas. O cavalo marinho tem uma estrutura complexa, enredo fixo e diversos elementos encadeados que se sucedem ao longo da noite. Reúne dança, encenação, música, figuras mascaradas, sacralidade, poesia, humor e muitos mistérios.

Ao longo de dez anos de pesquisa e convivência com fazedores de cavalo marinho, observei diversas mudanças tanto nos modos de organização dos grupos como na estrutura e na estética da brincadeira. Essas mudanças, observadas em um período relativamente curto, me levaram a refletir sobre o caráter dinâmico das tradições populares. Assim, neste trabalho e também no que concerne à minha produção artística, lido com o cavalo marinho em uma

\footnotetext{
${ }^{1}$ Instituto de Federal de Goiás, Aparecida de Goiânia, GO, Brasil.
} 
perspectiva dinâmica que reconhece que seus sujeitos estão em constante fluxo de troca com eventos da contemporaneidade.

Utilizo o conceito de tradição no sentido de que o brinquedo tem características que se mantêm e se renovam ao longo do tempo e são passadas de geração a geração por via oral. Da mesma forma, refuto um olhar folclorizador que tende a minimizar as manifestações populares e enalteço o cavalo marinho como uma expressão artística de grande valor, sendo rica em princípios técnicos e estéticos que dialogam e contribuem com a produção contemporânea de teatro e dança.

Quando conheci tradições como o frevo, os cavalos marinhos, maracatus, caboclinhos, côcos, entre outras, percebi uma certa vigorosidade e precisão que iluminavam caminhos para outro tipo de qualidade de movimento e de presença cênica, diferente daquela a que eu estava acostumada, como dançarina de formação acadêmica. Foi então em noites varadas em festas de Batuque de Umbigada pelo interior de São Paulo que descobri certo gosto pela pesquisa de campo, por conhecer comunidades tradicionais e participar de rituais festivos.

Parto de um interesse genuíno pelas culturas populares e pela potência que essas têm de diversificar os repertórios corporais e ampliar nossa experiência estética. Em processos de investigação sobre as manifestações expressivas da nossa cultura tradicional, enfatizo a importância de se empreender pesquisas de campo, aproximar-se dos fazedores e seus mundos. A partir de 2005, me aprofundei na investigação sobre o cavalo marinho pernambucano. Minha trajetória como artista-pesquisadora desde então é pautada pela criação e atuação em obras contemporâneas de dança e teatro que partem do diálogo com elementos das culturas populares e suas possibilidades de re-invenção na cena. Dois trabalhos que marcam fortemente essa trajetória são: o espetáculo teatral Gaiola de Moscas ${ }^{2}$ e o solo de dança Guarda Sonhos ${ }^{3}$, ambos desenvolvidos no contexto do Grupo Peleja, coletivo de artistas surgido em Campinas/SP do qual fui integrante e co-fundadora.

Os dois trabalhos mencionados partem de uma premissa base que é a vivência junto ao brinquedo, seus sujeitos e tudo que o cerca. Os anos de pesquisa de campo foram experiências que sempre me exigiram engajamento corporal e abertura interna. $\mathrm{O}$ cavalo marinho me revela um mundo de contradições que me permite perceber meu próprio corpo, além de me colocar numa situação de estrangeira. Essa experiência pode ser compreendida como viagem no sentido proposto por Michel Onfray, em Teoria da viagem: poética da geografia (2009). O autor se refere à qualidade do bom observador, que ele chama de nômade-artista, enfatizando que a viagem se apresenta como uma situação privilegiada, pois o corpo "abalado, tenso e disposto a novas experiências, registra mais dados que de costume" (p. 49).

Assim, imersa em uma pesquisa de campo que pode ser entendida como criação, como viagem, assumi a mim mesma como suporte das experiências vividas. "Viajar solicita uma abertura passiva e generosa a emoções que advêm de um lugar" (Onfray, 2009, p. 59). É preciso estar aberto para perceber e acolher o que se passa entre o espetáculo de um lugar e nós, e é essa disponibilidade interna que me é solicitada em meu trabalho. Meu exercício criativo vem no sentido de organizar o caos provocado por essa experiência, numa tentativa de traçar linhas de força, pontos de fuga, abrir passagem às energias, produzir sentido.

\section{A brincadeira do Cavalo Marinho pelos olhos de uma dançarina-pesquisadora}

A Zona da Mata Norte de Pernambuco é nascedouro e palco de uma sofisticada produção cultural que abarca grupos de cavalo marinho, maracatus de baque solto, mamulengos, cirandas, caboclinhos, mestres rabequeiros, cantadores, tocadores, figureiros, sambadores, brincadores.

\footnotetext{
${ }^{2}$ Gaiola de Moscas (2007), direção de Ana Cristina Colla (Lume Teatro), é adaptado do conto homônimo do escritor moçambicano Mia Couto.

${ }^{3}$ Espetáculo solo (2009) do qual sou intérprete e criadora.
} 
Nessa mesma região, contraditoriamente, as desigualdades sociais são acentuadas e percebemos a permanência de uma economia baseada na monocultura da cana-de-açúcar, na exploração do trabalhador rural, altos índices de analfabetismo, subordinação da mulher e violência de gênero.

Um cavalo marinho dura cerca de nove horas, iniciando de noite e terminando quando o sol se levanta, a "barra do dia". O mote da brincadeira é um baile em louvor aos Santos Reis do Oriente oferecido pelo Capitão Marinho, figura central que enlaça a história encenada. Para tomar conta da festa, ele contrata os "nêgos"4 Mateus e Bastião, figuras também presentes em outras tradições brasileiras. Com texto fixo e uma atuação dançada, figuras mascaradas se apresentam ao longo noite, ao som de música ao vivo feita por tocadores sentados em um banco de tábua. Os sujeitos da brincadeira são, em sua maioria, homens de corpos precisos, detentores de técnica altamente específica, com notável agilidade física e mental.

Os cortadores de cana trabalham por safra, ou seja, apenas nos meses em que são recrutados pelas usinas, numa jornada pesada e mal remunerada. A lida com a cana envolve diversos tipos de serviço, todos eles bastante exigentes de força, resistência física, agilidade e destreza com as ferramentas. A brincadeira se configura, assim, como momento/espaço em que se recria uma realidade, em que se está junto a um coletivo não para trabalhar, mas para cantar, dançar, fazer verso e dar risada. É como uma fenda aberta na pressão do cotidiano, uma possibilidade de suspender temporariamente a realidade e ressignificar a vida.

O cavalo marinho espelha em sua dinâmica aspectos do trabalho físico pesado. Poderíamos dizer que o cavalo marinho é uma brincadeira "pesada". A música, alta e vigorosa, é ligeira e remete a galopes de cavalo. O banco de tocadores é composto por rabeca (parente do violino), pandeiro, mineiro (ou ganzá) e bage (espécie de reco-reco feito de bambu). O som ritmado das bexigas de boi cheias de ar que Mateus e Bastião usam para bater nas pernas e nas pessoas complementam a batida do banco. As músicas são chamadas de toadas e os versos de loas, e cada toada, cada loa se refere a um momento específico da brincadeira, ou é característica de uma figura.

Cantar e tocar em um banco de cavalo marinho a noite toda é tarefa que exige dos dedos, do juízo e da "goela". A parte dançada na brincadeira é também bastante exigente, requer fôlego e preparo físico. Nas rápidas dinâmicas corporais do cavalo marinho, os pés batem secos no chão seguindo uma acentuação rítmica não usual que confere à dança certa dificuldade na execução. Há que ter uma "lubrificação" nos joelhos, um molejo nas pernas e uma habilidade para subir e descer rapidamente. Os corpos e as histórias de vida dos brincadores estão marcados pelo trabalho no corte da cana, e isso se encontra bastante presente no gestual, no emprego do corpo ao realizar a dança e também nas toadas de cavalo marinho, que geralmente fazem referência a esse cotidiano, mas também falam de amor e das relações pessoais.

\section{A dança}

A dança é minha principal via de acesso à brincadeira. Compreendo a dança como código comum a partir do qual os corpos se organizam e adquirem particularidades. Cada brincador tem uma maneira própria de sambar. Apesar de haver uma forma padrão, uma acentuação rítmica correta, uma mecânica específica de cada movimento, é possível reconhecer diferentes maneiras de engajar o corpo: pequenas nuances evidenciadas no grau de tônus muscular empregado, uma qualidade explosiva em contraponto a outra contida, por exemplo.

Concordo com Eloísa Domenici (2009) quando ela afirma que é preciso criar novas epistemologias para a pesquisa sobre as danças tradicionais. Deslocando o eixo de análise para o corpo, ela propõe que, em lugar de passos ou coreografias, pode-se recorrer a categorias mais

\footnotetext{
${ }^{4}$ Mateus e Bastião são figuras sem máscara que aparecem com o rosto pintado com carvão preto. No enredo do cavalo marinho, eles são os empregados do capitão e, segundo muitos brincadores, representam negros cativos.
} 
produtivas para a análise, tais como o papel do jogo, os estados tônicos do corpo, as dinâmicas corporais específicas, as relações entre dança e cotidiano, e as dramaturgias que emergem do corpo. Adotar "dinâmicas corporais" no lugar de "passos de dança" me pareceu pertinente, pois implica uma preocupação com o todo da movimentação, com os princípios gerais, a variedade de dinâmicas, as qualidades corporais e padrões tônicos (aspectos que conferem certa singularidade a cada brincador), e não apenas o desenho do passo (aspecto comum a todos).

A dança no cavalo marinho se faz com dinâmicas corporais chamadas de trupés, tombo, pisada ou carreira; também por evoluções coletivas como a dança dos arcos; e por danças de interação, como o tombo do maguio, também chamado de mergulhão. Os brincadores dançam trupés no espaço interno da roda, nos intervalos entre a saída de uma figura e a entrada de outra. Também as figuras utilizam os trupés em suas performances.

$\mathrm{Na}$ dança dos arcos, os galantes, vestidos de branco, com chapéus e peitorais coloridos, cada qual com um arco feito de cipó enfeitado com muitas fitas coloridas, dispostos em duas filas chamadas cordões, dançam liderados pelo mestre. A performance dos galantes sob liderança do mestre é uma etapa longa e solene na brincadeira, pois em dado momento o banco de tocadores se levanta e todos, de pé, cantam juntos para a estrela guia em louvor aos Santos Reis do Oriente. Na dança dos arcos, os galantes unem as pontas dos arcos com as mãos de maneira a formar dois grandes cordões coloridos. As fitas balançam de um lado a outro de cada cordão, e os pés, ligeiros, batem no chão sincronizados. Na carreira, que são passos largos que permitem um deslocamento maior, os corpos dos galantes parecem deslizar sobre o solo, desenhando o espaço em círculos e oitos.

O mergulhão, maguio ou "tombo do maguio" é outro momento bastante popular no cavalo marinho e acontece logo no início da brincadeira. Bater o mergulhão é imprescindível para aquecer o corpo, as juntas, e ao mesmo tempo conectar-se com a brincadeira. As pernas formigam, o calor sobe, os pés e a mente ficam ágeis. As mudanças nos estados corporais são visíveis. O maguio pode ser descrito como um jogo de pergunta e resposta corporal, caracterizado pelo desafio e pela permanência de uma célula rítmica fixa. Todos se dispõem em frente ao banco de tocadores, formando uma meia-lua cujas pontas se unem pelo banco. Cada brincador entra e sai da roda fazendo, com os pés, uma célula rítmica padrão que não é feita pelos instrumentos, de maneira que a sonoridade dos pés batendo o chão complementa a música. É uma dança bastante ágil e vigorosa. Um brincador por vez se desloca até o meio da roda e, com olhar, movimento e intenção corporal, chama o próximo a entrar. O maguio é um momento prazeroso e recheado de tensão. Colocar-se na roda para jogar envolve risco. É motivo de vergonha ser derrubado pela rasteira do outro, ou não estar atento e deixar passar o momento certo de entrar na roda.

Embora alguns grupos já permitissem a participação de meninas, nos últimos 20 anos houve um significativo crescimento no número de mulheres a participar do cavalo marinho. São jovens e adolescentes, geralmente integrantes da família do Mestre, parentes ou amigas próximas daquele grupo familiar. As meninas participam ativamente das partes dançadas, realizando os trupés soltos, o tombo do maguio e a dança dos arcos. Em alguns grupos, as meninas são até maioria nos cordões da galantaria (imagem 1). 


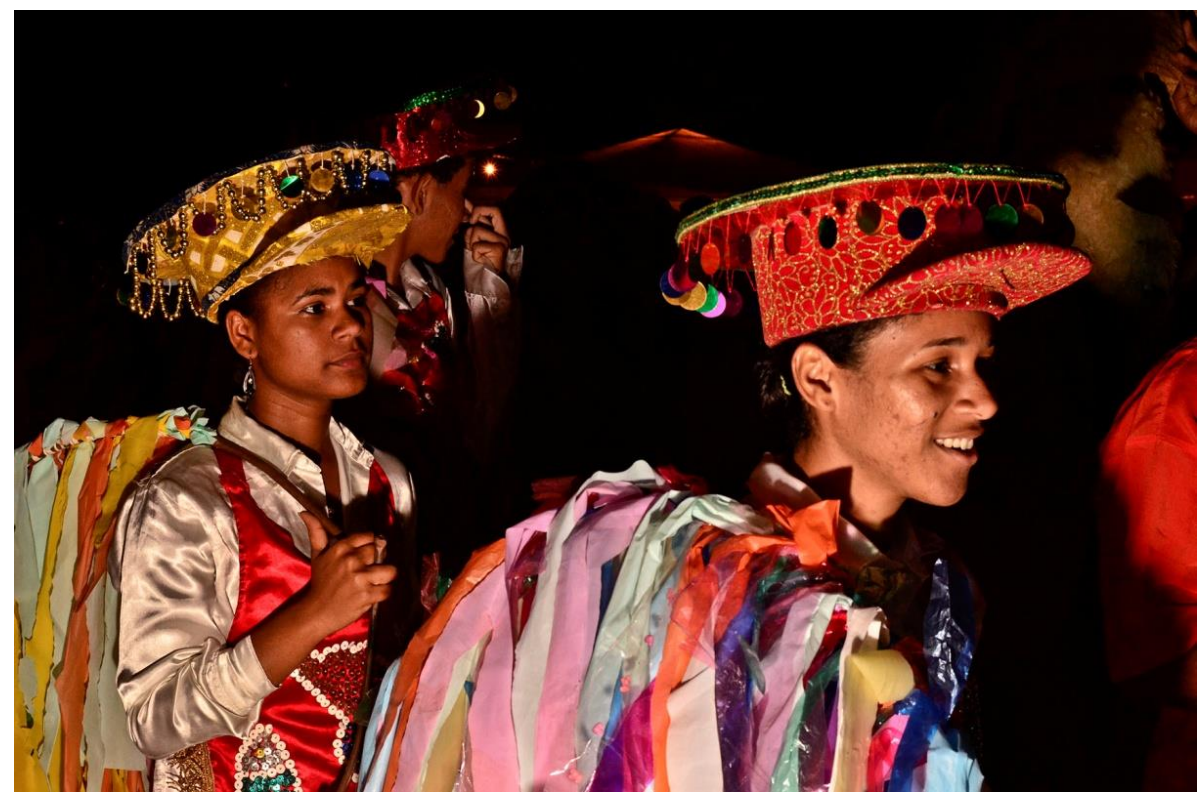

Imagem 1 - Meninas no cordão da galantaria do cavalo marinho Estrela de Ouro de Condado: Jaline Kelly e Eliana Silva, netas do mestre Biu Alexandre. Foto de Renata Pires.

\section{As figuras}

As figuras fazem a encenação no cavalo marinho. Uma após a outra, elas entram na roda do samba dançando ao som de uma toada específica, protagonizam uma cena e vão embora. Na maioria mascaradas, elas têm texto fixo, corporeidade e gestualidade típicas. De figura deriva a função figureiro, que é como se chama o brincador que "coloca" ou "bota" figuras. O sucesso da figura depende da destreza do figureiro, de sua capacidade de fazer rir, da habilidade em lidar com os elementos internos e externos à roda do samba.

As figuras são tipos que falam do amor, do trabalho, do cotidiano, das relações patrãoempregado, homem-mulher etc. Pequenas nuances do cotidiano são reveladas por elas. São as figuras que parafraseiam a realidade, que fazem da sexualidade motivo de piada, são elas que hiperbolizam as relações interpessoais e a vida cotidiana das pessoas (Acselrad, 2013). O humor do cavalo marinho está nas figuras.

Talvez por essa responsabilidade sobre a aprovação das pessoas e por serem as reais protagonistas no cavalo marinho é que as figuras sejam quase um tabu no tocante à participação da mulher. É raro que uma mulher coloque figuras. Mesmo as figuras femininas, são colocadas por homens. Quando uma mulher coloca figura, ela é imediatamente identificada e impõe-se na roda do samba uma atitude de respeito que não é comum. Inverte-se a lógica e as piadas não acontecem. Não há roçar dos corpos, não há o gesto obsceno, não há graça. Penso que no meio de cavalo marinho é distante das mulheres a possibilidade de fazer uso cômico do próprio corpo, inexiste a possibilidade de rirem de si mesmas ou de sua própria representação.

As figuras femininas das quais tenho conhecimento são colocadas por homens. Não tenho notícia de figura feminina sendo colocada por mulher. A começar pela Catirina - a nêga da perna fina -, cuja graça está justamente em ser colocada por um homem, sem máscara, com a cara pintada de carvão (assim como Mateus e Bastião). A Catirina (imagem 2) geralmente usa lenço na cabeça e um vestido que deixa o peito e as pernas peludas à mostra. Ela é propositalmente uma figura grotesca. A Véia do Bambu, ou Véia Dindinha, é talvez a mais conhecida das figuras femininas. É uma velha fogosa, que vai para a roda do cavalo marinho à procura do marido, o Véio Joaquim. Ela se abana e levanta a saia porque tem calor nas partes 
íntimas, agarra as pessoas, coloca os homens embaixo de sua saia dizendo "dá um cheiro aqui!". A Véia do Bambu (imagens 3 e 4) arranca gargalhadas de todos e todas.

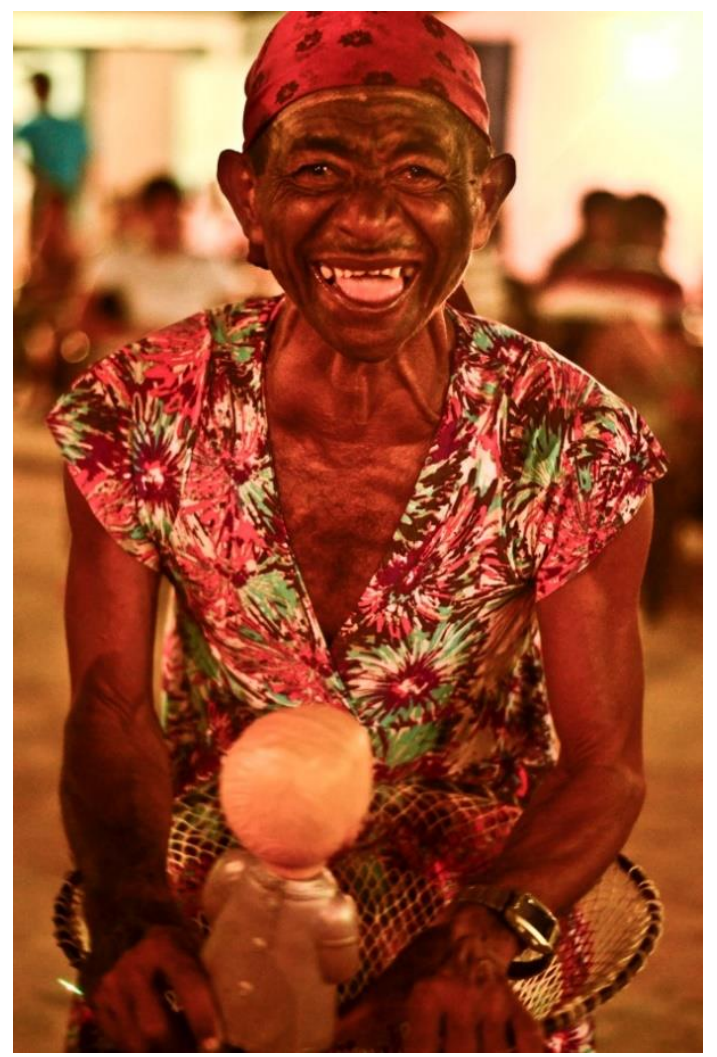

Imagem 2 - Catirina: figura feminina sem máscara colocada por José Carlos Silva (Pequinês), no cavalo marinho Estrela de Ouro de Condado, 2012. Foto de Renata Pires.

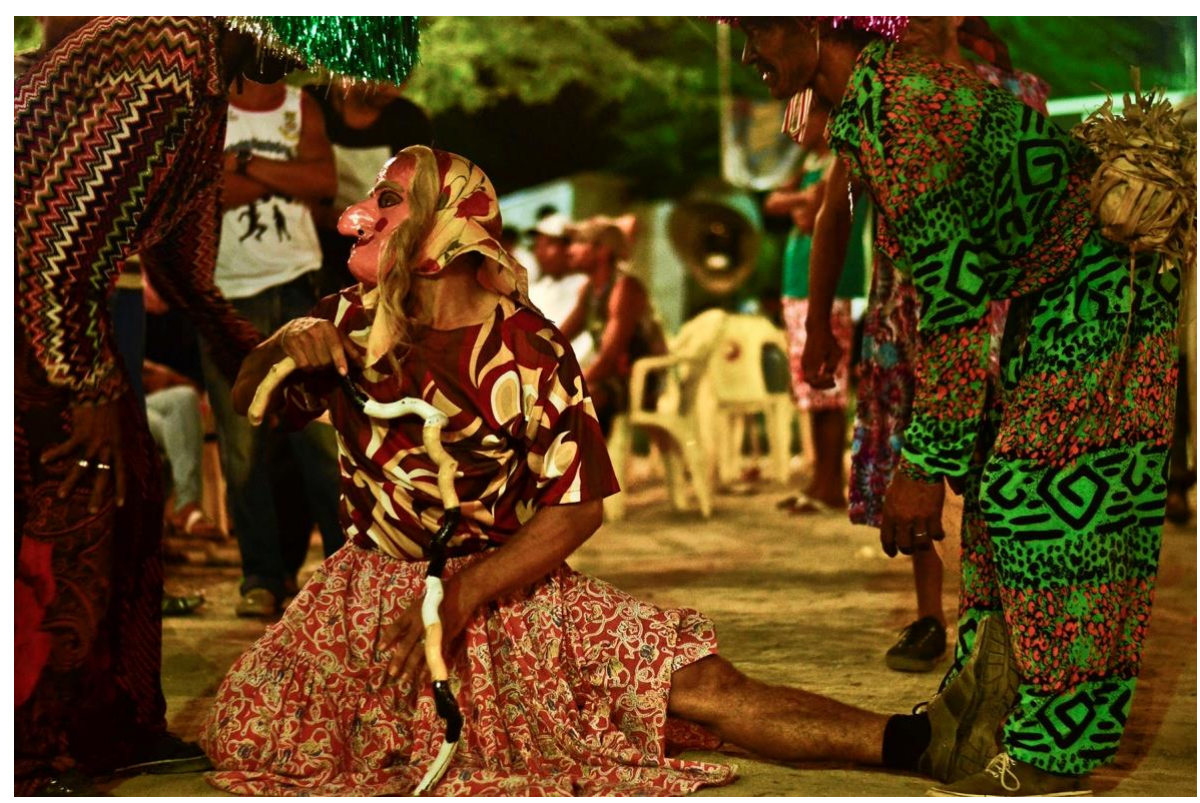

Imagem 3 - Véia do Bambu: figura feminina mascarada colocada por Aguinaldo Roberto da Silva, no cavalo marinho Estrela de Ouro de Condado, 2012. Foto de Renata Pires. 


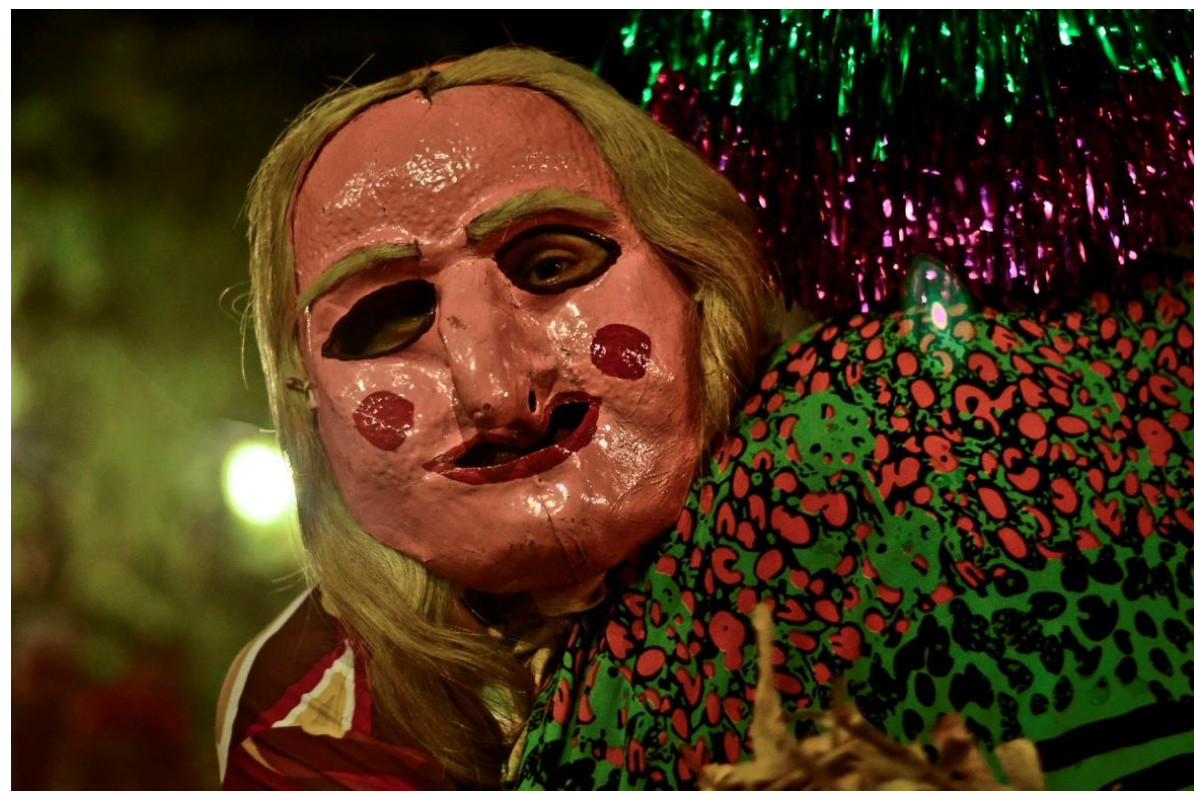

Imagem 4 - Véia do Bambu: figura feminina mascarada colocada por Aguinaldo Roberto da Silva, no cavalo marinho Estrela de Ouro de Condado, 2012. Foto de Renata Pires.

Outras figuras femininas menos conhecidas são a Lica da Peneira, que entra junto com o Pisa Pilão. Ela não tem fala e fica no fundo da roda peneirando farinha. A figura chamada Janabaia entra na roda toda enfeitada, usando óculos, brincos, colar, saia, lenço, guarda-chuva e um monte de acessórios. Aos poucos os galantes vão tirando as coisas dela, dizendo que são roubadas, até deixá-la sem roupa - no caso, de calção. Já a Nêga da Garrafa entra com um candeeiro aceso sobre a cabeça e dança. Ela também não tem fala. A boneca Margarida, outra figura feminina, vem acompanhando Mané Pequenino. Ambos são bonecos grandes cuja estrutura o figureiro ajusta sobre a cabeça, formando uma figura alta.

\section{A peleja das brincadoras na roda do samba}

Uma experiência que vale o relato é a de Jaclécia Roberta Silva, filha de Aguinaldo Roberto Silva. Jaclécia brinca no cavalo marinho Estrela de Ouro, de Mestre Biu Alexandre, seu avô. Este grupo é bastante considerado e conhecido, principalmente por ser constituído quase inteiramente por integrantes de uma mesma família. Jaclécia aprendeu a dançar com seu pai e começou a brincar aos 12 anos, no cordão da galantaria. Ela e sua prima Vinha foram bastante valorizadas no brinquedo. Jaclécia e Vinha chegaram a ocupar as posições de primeiro e segundo galantes, que são as mais importantes do cordão. Jaclécia também aprendeu a mestrar a dança dos arcos, ocupando esta função de destaque, para surpresa de seu avô.

No entanto, no desejo de botar figura, ela foi criticada e subestimada pelos primos, que não a autorizaram. Combinou, então, com a prima de colocarem, juntas, o Nego Quitanda. Assim como o Bode, o Nego Quitanda é uma figura que entra em dupla, em "pareia". É uma figura que não tem fala, ela vem para o samba somente para aprontar confusão. Um "pareia" entra na roda por vez fazendo coisas engraçadas e é sempre expulso por Mateus e Bastião sob bexigadas. Quando um sai, o outro entra. Assim, nessa atuação alternada, eles permanecem um bom tempo arrancando gargalhadas da plateia. Chegam dançando de um jeito mole e desengonçado; aparecem de surpresa por debaixo do banco de tocadores; pegam uma bicicleta de alguém e entram na roda com ela; roubam um objeto do público; aparecem dançando com 
cadeiras presas no corpo. E assim seguem, sempre apanhando da bexiga do Mateus e inventando algo inusitado para fazer, até serem expulsos da roda de vez.

Jaclécia conta que essa foi uma experiência desafiadora, ressaltando que era importante para ela provar que seria capaz de sustentar a figura por um longo tempo. Quando a prima quis encerrar a performance, visto que já tinham apanhado muito e estavam cansadas, Jaclécia foi veemente ao afirmar que era uma questão de honra. Rindo, ela lembra que suplicou à prima: "Vinha, por favor, não me deixe na mão... assim eles vão falar da gente! Cadê sua força, mulher?"5 .

Uma atmosfera bem diferente se apresenta no grupo de cavalo marinho Boi Brasileiro - de Mestre Biu Roque e hoje liderado pelo rabequeiro Luís Paixão -, onde também algumas meninas dançam na galantaria e põem figuras. As meninas que brincam no Boi Brasileiro não são todas da mesma família. Elas têm uma atitude bastante despojada em relação ao comportamento comum entre as mulheres da região. Fumam cigarros e tomam cerveja ao longo da brincadeira, o que não é muito comum. Simone, neta de Biu Roque, brinca no cavalo marinho desde os 10 anos e já experimentou diversas funções no brinquedo. Simone se diferencia da maioria das mulheres da comunidade do cavalo marinho porque é assumidamente homossexual e mora, com sua companheira, perto da casa da mãe. Esse fato é bastante extraordinário para o contexto de Condado.

Uma vez presenciei o seguinte: também colocando a figura do Nego Quitanda, Simone recebeu muitas bexigadas do nêgo Mateus. A interação entre os dois foi se desenvolvendo num crescente na roda do samba, de forma a se tornar cada vez mais caótica e violenta. Mateus nitidamente exagerava na surra de bexigas em um "pareia", a Simone, e aliviava a intensidade das bexigadas no outro "pareia", que eu não sei quem era. Foi uma situação agressiva e incômoda, com muitos puxões, empurrões e bexigadas. Em dado momento o Mateus veio por trás e passou a mão nas partes íntimas dela. Eu me surpreendi com aquilo. Quando comentei, ironicamente, sobre o ocorrido, ele me respondeu rindo: “É... com a Simone pode!". Nesse momento eu entendi tudo: a Simone não tinha um dono a quem ele devesse, na sua concepção, respeito.

Estes relatos são representativos de como se desenrolam as relações pessoais no mundo do cavalo marinho, de como homens e mulheres se relacionam, dentro e fora da brincadeira.

\section{A descontinuidade, a devoção e o humor}

O ritmo e o andamento do cavalo marinho, por estabelecerem certa descontinuidade na dramaturgia e uma constante quebra de sentido que surpreende o espectador, interessam ao meu trabalho de atriz-dançarina. Embora o cavalo marinho evidencie uma estrutura espetacular que obedece a determinado conjunto de regras, os eventos se sucedem de maneira não linear, alternando caos e organização sem prejuízo do andamento da brincadeira.

Há momentos em que as interferências externas fazem parte da encenação. O espectador pode conversar cotidianamente com algum brincador sem que isso atrapalhe o brinquedo. Há pausas para tomar uma cachaça e conversar. $\mathrm{O}$ banco pára de tocar por alguns minutos e retorna em seguida, assim como o público se dispersa e volta a se aglomerar em torno da roda momentos depois. Como observa Laranjeira, no decorrer da brincadeira "não há a necessidade de não revelar a ficção" (2008, p. 62). Nesse caos organizado, há momentos em que tudo vai bem e outros em que o brinquedo parece "desmantelado". O desmantelo, no entanto, é parte da estrutura, pois a fragmentação e a descontinuidade fazem parte do ritmo natural da brincadeira.

Crença religiosa, fé e espiritualidade também se manifestam na roda do cavalo marinho. Religiosidade não é a característica principal uma vez que a dimensão profana, se assim podemos dizer, o humor malicioso, a paródia das relações entre patrão e empregado, até mesmo

\footnotetext{
${ }^{5}$ Este relato é parte de uma entrevista a mim concedida em dezembro de 2012, em Condado (PE).
} 
uma suposta crítica social são as características mais associadas ao cavalo marinho. Contudo, a brincadeira traz momentos de louvação a Jesus Cristo e aos Santos Reis do Oriente, e também momentos ritualísticos, com referências ao culto da Jurema, na figura do Caboclo Arubá. Esta figura nos transporta para um ambiente completamente distinto daquele cômico e jocoso que impera na brincadeira. A atuação do caboclo, as belas toadas, juntamente com a ação de pisar e deitar-se sobre os cacos de vidro, impactam o público e impregnam a roda de samba de certo mistério, de uma ambiência sagrada.

Fora esses momentos em que predomina uma atmosfera mais solene, o restante do cavalo marinho é cômico, jocoso, repleto de malícias. Assim, nos demais momentos e no mote das outras figuras, impera uma "safadeza", um tipo de humor (profano) bastante característico dos brincadores. A dimensão do sagrado, no entanto, está presente em todo o cavalo marinho, manifestando-se na relação que os brincadores estabelecem com a brincadeira, no cuidado que têm com ela, na preparação que realizam para que o cavalo marinho aconteça.

Em relação ao humor, podemos dizer que a "vadiagem" e a provocação são elementos que caracterizam uma certa "safadeza" nos brincadores. O gosto pelo jogo, pela farra, e também pelo trocadilho, pela inversão, pela frase de duplo sentido e de conteúdo sexual caracterizam a natureza do humor que permeia a brincadeira e, principalmente, as figuras. O risível está naquilo que a forma e o conteúdo da piada vêm trazer à tona (Acselrad, 2012, p. 147), no gesto obsceno, no dizer as coisas pela metade. A piada está não somente na simulação do ato sexual, mas em subjugar o outro. São piadas de um universo masculino, cuja graça é compartilhada principalmente entre os homens. Os figureiros utilizam metáforas e palavras muitas vezes irreconhecíveis. Eles se divertem entre si com "puias" que ninguém mais entende. A "roda" do outro é sempre o lugar visado. O botar algo "no fundo" é o que conduz às gargalhadas. A "puia" do cavalo marinho, no fim das contas, é sempre sobre o "butico".

Dirigir um olhar cuidadoso para os sujeitos do cavalo marinho me pareceu um caminho profícuo para traçar as relações de continuidade que se estabelecem entre a vida cotidiana e a brincadeira. A alusão ao sexo e a dose de agressividade inerente à sua representação são elementos condutores do humor no cavalo marinho. Percebê-las ajuda a dimensionar a importância do corpo para a compreensão das relações de gênero e da condição da mulher no universo desta brincadeira.

\section{Um olhar para as mulheres no Cavalo Marinho}

Partindo da observação de que as mulheres são muito mais ausências do que presenças na brincadeira e de que a importância de sua participação se dá em outra esfera que não o protagonismo na cena do cavalo marinho, passei a me perguntar o que as mantém ligadas a essa tradição. A partir de 2011, aprofundei minha vivência com algumas mulheres da cidade de Condado (PE) que têm relação direta com o cavalo marinho, seja porque brincam ou porque colaboram com o brinquedo sendo esposas e parentes de algum brincador ${ }^{6}$. Passei a perceber mais atentamente o movimento delas, sempre no sentido de zelar pelo bom andamento das coisas. Passei também a ouvir com mais interesse suas conversas, suas histórias, suas versões sobre fatos que eu conhecia previamente de outra forma.

Para tratar de um universo feminino, precisei operar uma significativa mudança no meu olhar para o cavalo marinho, justamente procurando enxergar o que não está visível, o que não salta aos olhos, o que é bastidor de uma cena masculina. Foi necessário modular o olhar para

\footnotetext{
${ }^{6} \mathrm{O}$ universo das mulheres em torno do cavalo marinho é tema da dissertação de mestrado que defendi no Programa de Pós-Graduação em Arte da Universidade de Brasília (UNB) em 2014, sob orientação do Prof. Dr. Jorge das Graças Veloso, na linha de pesquisa Processos Composicionais para a Cena.
} 
ver às avessas. Foi necessário ver de dentro, dando espessura às situações banais, às conversas de cozinha e ao que antes eu considerava um fazer recheado de não-fazer.

No exercício de procurar esse novo olhar, mais perspicaz e atento para um mesmo objeto sempre olhado, lancei mão do que propõe a artista plástica Karina Dias em suas reflexões sobre paisagem e sobre exercitar o que ela chama de um olhar-em-paisagem. Sobre os mecanismos de visão e do que ela chama de in-visão, escreve Dias:

Pensar que em todo visível há um in-visível, em todo visto um 'ainda-nãovisto' e em cada olhar portado, em cada visão, uma invisão, uma ressonância interna que entra em cena e se revela como um campo inesgotável a ser explorado (2010, p. 115).

Nesse processo de pesquisa sobre o universo feminino em redor do cavalo marinho, trabalhei sobre as narrativas pessoais de seis mulheres que me concederam entrevistas, depoimentos, cafés, biscoitinhos, dedos de prosa e muita confiança. São elas: Jaclécia Roberta da Silva (neta de Mestre Biu Alexandre), Ivanice Maria do Carmo (esposa de Aguinaldo Roberto da Silva, filho de mestre Biu Alexandre), Maíca (filha do falecido Mestre Biu Roque), Dona Didi (esposa de Seu Martelo, o mais famoso nêgo Mateus da região), Dona Preta (sogra de Aguinaldo Roberto da Silva) e Dona Biu (ex-esposa de Mestre Biu Alexandre, mãe de seus filhos adultos brincadores do Estrela de Ouro).

Uma maneira de me aproximar delas foi ouvir suas histórias. As narrativas pessoais se mostraram mecanismo revelador de um mundo feminino rico e controverso, que não tem apelo na roda de samba do cavalo marinho, mas é parte da vida das pessoas que o fazem. São as lembranças das mulheres que tocam o domínio da família, da maternidade, da vida privada e doméstica. Nas conversas com as mulheres, a sexualidade não é motivo de piada.

Os relatos selecionados para compor a dissertação que é base para esse artigo foram obtidos entre agosto e novembro de 2012. As perguntas eram sobre as memórias da infância, da mocidade e do tempo em que eram solteiras. Sobre a experiência do amor, da maternidade, sobre o que aprenderam com suas mães e avós. Também perguntei como se sentem em relação ao cavalo marinho. Daquelas que brincam, quis saber como e quando começaram, as dificuldade encontradas, que alegrias têm ao participar do brinquedo. Essas perguntas foram importantes em um primeiro momento, pois serviram como disparadores das memórias.

Relacionar as reflexões de gênero à pesquisa de campo sobre o cavalo marinho foi algo delicado. O cavalo marinho carrega beleza e poesia ao mesmo tempo que reflete uma realidade bastante dura, tanto para homens quanto para mulheres. As questões femininas, no entanto, não têm apelo na roda do cavalo marinho uma vez predomina nesta brincadeira uma representação masculina do mundo. Não há figuras que representem a mulher em outra função que não seja fazer rir de sexo. Não há "a professora", "a parteira", "a costureira", "a florista", ou tantas outras figuras que pudessem caracterizar tipos femininos presentes no cotidiano da comunidade do cavalo marinho.

As mulheres que brincam precisam se moldar a uma certa maneira de se comportar e limitam-se a ocupar os lugares que lhes são permitidos. Mas isso não as diminui nem as exclui da dinâmica da brincadeira. A força das mulheres se expressa em outros espaços. Além de se envolverem na feitura de roupas e adereços, percebo que elas harmonizam as relações e, de certa, forma regulam a dose de agressividade que é característica dos brincadores. A presença das mulheres no público, principalmente das esposas, garante o bom andamento do brinquedo. 


\section{Considerações finais}

Minha abordagem sobre o cavalo marinho, enquanto alguém que enxerga o mundo pela ótica do movimento e tem o corpo como lugar de acomodamento e recriação das experiências, é uma abordagem que privilegia a pesquisa de campo e o poder que esta tem de nos afetar. Mais que um procedimento emprestado da Antropologia, a pesquisa de campo aqui se configura como uma necessidade de colocar o corpo na experiência. Trata-se de aguçar a percepção e apreender um mundo outro a partir da sensorialidade. Porque promoveu em mim um choque de realidades e ainda me permitiu agregar informações corporais extremamente distintas, descrevi a pesquisa de campo sobre o Cavalo Marinho como viagem, como criação, como mergulho rumo ao desconhecido (Onfray, 2009).

Ao coletar depoimentos de mulheres colhidos em campo, tive a intenção de trazer para a luz aquilo que poderia ser descrito como bastidores ou que aparentemente não tem importância nem apelo na roda de samba do cavalo marinho. Os relatos das mulheres me revelaram as histórias que acontecem por trás da história contada no cavalo marinho. Revelaram muito daquilo que não é parte da brincadeira mas que, paradoxalmente, é essencial para que ela aconteça do modo como acontece.

A dinâmica desigual entre homens e mulheres é expressa no cavalo marinho na clara limitação da participação feminina, nas piadas e no mote das figuras. Coube a mim observar que espaços é permitido às mulheres ocupar. Atentando para suas histórias privadas, passei a dar importância às experiências que compõem um rico universo feminino vivenciado às margens do cavalo marinho, mas que faz parte dele. O cavalo marinho não aconteceria do modo como acontece se não fosse a atuação das mulheres em tais tarefas "secundárias", e por esse motivo eu as considero fazedoras dessa manifestação tanto quanto os homens o são.

Penso que este trabalho pode enriquecer as reflexões sobre criação em dança, as pesquisas sobre manifestações expressivas da cultura brasileira e os estudos sobre o cavalo marinho. No tocante às questões de gênero inerentes a essa manifestação, acredito que a maior contribuição seja revelar aspectos não evidentes, oferecendo um olhar singular, um ângulo de visão deslocado. Os "assuntos femininos" se tornaram visíveis justamente por terem sido observados por uma pesquisadora mulher. Foram eles também que, articulados com o repertório corporal do Cavalo Marinho, viraram mote para a criação artística que complementou a pesquisa acadêmica.

A produção intelectual e artística feminina traz novos coloridos e novos contornos para o mundo acadêmico (Rago, 1998). Pretendi com este trabalho oferecer uma visão sobre o cavalo marinho que diversifica suas formas de interpretação e apresenta um ponto de vista dificilmente imaginável sob a ótica masculina. O trabalho de Dança que se desdobrou das reflexões aqui apresentadas foi um exercício cênico-coreográfico intitulado "Ausências" (2013). O link para acesso no youtube é: http://youtu.be/gK7wgE7AQkM.

\section{Referências}

ACSELRAD, Maria. 'Viva pareia!' Corpo, dança e brincadeira no cavalo-marinho de Pernambuco. Recife: Ed. Universitária da UFPE, 2013.

DIAS, Karina. Entre Visão e Invisão: paisagem. 1. ed. Brasília, DF: Ed. UnB, 2010.

DOMENICI, Eloisa. A pesquisa das danças populares brasileiras: questões epistemológicas para as artes cênicas. Cadernos do GIPE-CIT (UFBA), v. 23, p. 7-17, 2009. 
LARANJEIRA, Carolina Dias. Corpo, cavalo marinho e dramaturgia a partir da investigação do Grupo Peleja. Dissertação de Mestrado. Instituto de Artes, Universidade Estadual de Campinas, Campinas, 2008.

ONFRAY, Michel. Teoria da viagem - poética da geografia. Porto Alegre: L\&PM editores, 2009.

PIRES, Renata. Registro fotográfico do projeto de pesquisa Ausências Presentes: corpos femininos em trança, FUNCULTURA / PE, 2012.

RAGO, Margareth. Descobrindo historicamente o gênero. Cadernos Pagu, n. 11, p. 89-98, 1998.

\section{Sobre a autora}

Tainá Barreto é dançarina, criadora, educadora do movimento e pesquisadora das culturas tradicionais brasileiras. É Bacharel e Licenciada em Dança pela UNICAMP, Especialista em Dança pela Faculdade Angel Vianna e Mestre em Arte pela UNB. É docente da Licenciatura em Dança do Instituto Federal de Goiás IFG / campus Aparecida de Goiânia.

E-mail: tainabarreto@yahoo.com.br. 